\title{
МОНГОЛ, ЯПОНЫ ДИПЛОМАТ ХАРИЛЦАА: ГУНЗГИЙРЭЛ, ЧИГ ХАНДЛАГА
}

\section{Б.Сэржав}

Монгол Улс Япон улстай дипломат харилщаа тогтоосноос хойш 45 жсилийн хугащаа улиран одлоо. Энэ харилцаа Хүйтэн дайны үе болон сочиалист системийн уналтаар Монгол Улс ардчилал, зах зээлийн тогтолцоонд шилжсин цоо иинээр хөгжлийн гарааг эхэлсэн огиом хувьсал бүхий өвөрмөи түҮхэн ияаг хугащааны сорилтыг туулљ, хамтын ажсиллагаа өргөжив. Эдүгээ хоёр орны харилцаа Иж бүрэн түншлэлийн харилцаанаас Стратегийн түнилэл, Эдийн засгийн түншлэлийн түвшинд хүрч гүнзгийрэн хөгжиж байна. Эдийн засгийн түншлэлийн хамтын ажсллагаа, стратегийн түншлэлийн дунд хугацааны шинэ хөтөлбөрийн хэрэгжилт нь хоёр орны хамтын ажсиллагааны өнөөгийн өргөн боломжийг бүтээлчээр ашиглаж Япон улсын дэлхийд хүлээн зөвщөөрөгдсөн тэргүҮний технологи, ноу хау, шилдэг туршлага, менежментий өөрийн онилогт тохируулан нэвтриүлэх, түҮний үндсэн дээр үндэсний үйлдвэрлэлийг хөгжүүлж өрсөлдөх чадвараа дээшлүүлэх, эдийн засгийн бие даасан байдльг бататгах, улс орныг авч явах үндэсний боловсон хүчнээ бэлтгэх зэрэг өргөн хүрээтэй бололиоог олгож байна.

Түлхүур үг: Монгол, Японь дипломат харилиаа, Монгол Улсын ардчилал, зах зээлийн тогтолиоо, Монгол, Японы Стратегийн түншлэл, Монгол, Японь Эдийн засгийн түншлэл 


\section{Харилцааны эхэн уе}

Одоогоос 45 жилийн тэртээ 1972 оны 2 дугаар сард Монгол Улс Япон улсын хооронд дипломат харилцаа тогтоох түүхэн үйл явдал болж, 2 дугаар сарын 24-ний өдрийн 11 цагт Москва хотноо Япон улсын Элчин сайдын яамнаа БНМАУ-ын Онц бөгөөд бүрэн эрхт Элчин сайд Н.Лувсанчүлтэм, Япон улсын Онц бөгөөд бүрэн эрхт Элчин сайд К.Нийзэки нар БНМАУ, Япон улсын хооронд дипломат харилцаа тогтоосныг нотолж, нот солилцжээ. Энэ ёслолд манай талаас Москвад суугаа ЭСЯ-ны зөвлөх Б.Дашцэрэн, нэгдүгээр нарийн бичгийн дарга Ч.Хунжав, атташе Б.Нацагдорж, МОНЦАМЭ агентлагийн сурвалжлагч Э.Түмэнжаргал нар, Японы талаас Элчин зөвлөх Т.Хасэгава, зөвлөх К.Чиба, нэгдүгээр нарийн бичгийн дарга К.Нишида, атташе Х.Үэда нар байлцжээ. Энэ өдрийг хоёр орны хооронд дипломат харилцаа тогтоосон өдөр гэж тооцохоор тогтсон ${ }^{1}$ түҮХТэй.

“БНМАУ, Япон улсын хооронд дипломат харилцаа тогтоосон тухай хамтарсан Албан мэдээ” тухайн үед Үнэн сонинд нийтлэгдэж, “...БНМАУ, Япон улсын хооронд дипломат харилцаа тогтоосон нь хоёр орны эдийн засаг, соёлын хамтын ажиллагааг хөгжүүлэхэд тус дөхөм үзүүлнэ гэдэгт итгэж байгаагаа хоёр тал илэрхийлэв"2 хэмээн тэмдэглэжээ. Энэхүү хамтарсан албан мэдээ Японд Дэейли Ёмиүри (1972.02.22), Майничи (1972.2.23), Санкэй (1972.2.19) сонинд нийтлэгдэж байв.

Тухайн цаг үеийн Монгол Улс, Япон улсын нийгэм, эдийн засгийн тогтолцоо, болж өнгөрсөн түүхэн үйл явдлын үр нөлөө, дэлхий дахины олон улсын нөхцөл байдлын асуудал зэрэг хүчин зүйлээс улбаатай төвөг бэрхшээлийг даван туулж, Монгол, Японы хооронд дипломат харилцаа тогтоосон нь тус хоёр орны үндэсний эрх ашигт бүрнээ нийцэж, хоёр орны харилцааны түүхэнд тохиосон онцгой чухал үйл явдал болсон юм. Япон улстай албан ёсны дипломат харилцаа тогтоосноор

- Хоёр орны найрсаг харилцаа, хамтын ажиллагаа цоо шинэ шатанд өргөжин хөгжих түүхэн таатай боломжийг анх удаа нээж өгсөн.

\footnotetext{
Монгол Улсын Гадаад харилцааны яамны архив, Ф-59, хн-66.
}

2 Үнэн сонин,Улаанбаатар, 1972.02.19. 
- Харилцаа хэвийн болсноор хоёр орны ард түмний хооронд оршсоор ирсэн харилцан үл итгэлцэх, үл ойлголцох байдал, Монголын нийгэмд бугшсан Японтой холбоотой түгшүүр, хардалтын уур амьсгал эрс намжихад чухал түлхэц үзүүлсэн.

- Өрнөдийн гүрнүүдээс зөвхөн Их Британи Улстай дипломат харилцаатай байсан манай улсын хувьд гадаад харилцаагаа тэлэх томоохон алхам болж, дэлхийн тавцанд Монгол Улсын гадаад бодлого, нэр хүнд өсч бэхжихэд тус болсон.

Мөн Монгол Японы хооронд дипломат харилцаа тогтоосон түүхэн үйл явдлын ач холбогдлыг цаг хугацаагаар хязгаарлах аргагүй, XX зууны 90-ээд оноос хойших Монгол Улсын ардчилсан хөгжлийн үе шатан дахь хоёр орны харилцааны үр шим шинэ зууны хөгжлийн стратегийн хэрэгжилттэй ч холбон үзэх ёстой хэмээн бодно ${ }^{3}$.

Япон улстай тогтоон хөгжүүлсэн хоёр талын харилцаа эхний үед дэлхий дахин хоёр туйлд хуваагдан бие биеийн эсрэг сөрөн зогсч байсан Хүйтэн дайны үе болон социалист системийн уналтаар Монгол Улс ардчилал, зах зээлийн нийгэмд шилжин цоо шинэ үе шатанд хөл тавьж, хөгжлийн гарааг эхэлсэн огцом хувьсал бүхий өвөрмөц түүхэн цаг хугацааг туулсан билээ. Өнөөдөр Стратегийн түншлэл, Эдийн засгийн түншлэлийн шатанд хүртлээ өөдлөн дэвшиж, өсөн хөгжиж буй хоёр орны харилцааны хөгжлийн үе шат, онцлог хийгээд цаашдын хандлагын талаар энд товч өгүүлэхийг зорив.

Юуны өмнө харилцааг хэвийн болгох үйл явц түүхэн цаг үеийн зарим асуудлын нөлөөгөөр тодорхой хугацаагаар сунжирсан хэдий ч хоёр талын дипломатчдын хүчин зүтгэлээр дипломат харилцаа байгуулсны дараа шинэ тутам харилцааг боломжтой хэлбэрээр урагшлуулан ахиулах алхмыг шуурхай бөгөөд амжилттай хэрэгжүүлж эхэлсэн гэдгийг тэмдэглүүштэй. 1974 оны 9 дүгээр сарын 23-нд "Монгол, Японы Засгийн газрын хооронд соёлын харилцаа тогтоосон тухай ноот бичиг" солилцсон нь соёл, урлаг, боловсрол, шинжлэх ухаан, хэвлэл мэдээлэл зэрэг салбарт хамтын ажиллагаа хөгжүүлэх эрх зүйн чухал үндэс болж, харилцаа холбоо

3 Б.Сэржав, “Монгол Японы хооронд дипломат харилцаа тогтсон нь, ач холбогдол”, Монгол Японь харилцаа: Өнгөрсөн ба эдүгээ (ХХ зуун), Бемби сан хэвлэлийн газар, Улаанбаатар, 2011, 263 дугаар тал. 
шинэ хэлбэрээр өргөжин тэлэх таатай нөхцлийг бүрдүүлсэн билээ. БНМАУ, Япон улсын хооронд эдийн засгийн салбарт хамтран ажиллах тухай хэлэлцээр 1977 оны 3 дугаар сард байгуулагдсаны дагуу Япон улсын Засгийн газрын 5 тэрбум иен ${ }^{4}$ (тухайн үеийн ханшаар 17 сая ам.доллар)-ий буцалтгүй хөрөнгийн тусламжаар, жилд 1000 тн ямааны ноолуур, 200 тн тэмээний ноос боловсруулах хүчин чадалтай Говь комбинатыг байгуулж, 1981 онд ашиглалтад оруулсан. Энэ үйлдвэр манай улсын гадаад худалдаа, ялангуяа өрнөдийн орнуудтай хийх худалдаа эрс өргөжихөд чухал үүрэг гүйцэтгэсэн. Монгол, Японы худалдаа огцом өсч, 1989 онд нийт эргэлт нь 31 сая шахам ам долларт хүрч, Япон улс манайхаас 250 гаруй сая долларын ноолууран бүтээгдэхүүн импортолсон нь Монголоос оруулсан импортын 70 гаруй хувийг ${ }^{5}$ эзэлж байжээ.

1980-аад оны дунд үеэс ЗХУ-д өөрчлөн байгуулалт эхэлж, гадаад харилцаанд нь улс төрийн шинэ үзэл санаа хэрэгжин Зөвлөлт, Америкийн харилцаа сайжирч, манай оронд ч өөрчлөлт шинэчлэлтийн бодлого явагдан дэлхийн улс орнуудтай харилцаа, хамтын ажиллагаагаа өргөтгөн тэлэхэд анхаарч эхэлсэн юм. Энэ чиг хандлага Япон улстай харилцах харилцаанд тусгалаа олж, 1987 онд Монгол Улсын Гадаад явдлын яамны сайд М.Дүгэрсүрэн Япон улсад анх удаa, 1989 онд Япон улсын Гадаад хэргийн сайд С.Үно өндөр хөгжилтэй орны Гадаад хэргийн сайд нараас анх түрүүн манай улсад албан ёсны айлчлал хийв.

1980-аад оны сүүлч гэхэд хоёр орны харилцаа улс төр, худалдаа эдийн засаг, соёл, боловсрол шинжлэх ухаан зэрэг салбарыг хамран хэвийн тогтвортой урагшлан харилцан ойлголцол дээшилж, шинэ шатанд дэвших төлөв хандлагаар тодорхойлогдох болсон нь энэ үеийн харилцааны хөгжлийн нэгэн чухал онцлог байв. Ийм онцлог байдал бүрдсэний бодит хүчин зүйл нь “нэгд, дипломат харилцаа тогтоосны дараа харилцааг хэвийн тогтвортойгоор урагшлуулахад хоёр тал ихээхэн идэвхи чармайлт гаргасны үр дүн, улмаар 50-иад оноос эх үүсвэр нь тавигдаж, алгуур аажим боловч урагшилж ирсэн хамтын ажиллагааны ашиг сонирхол, үзэл санаа ойртож, туршлага,

4 Монгол Улсын Гадаад харилцааны яамны архив, Ф-59, хн-105

5 Такасэ Хидэказү, Жингисү кан-но күни-э (Чингис хааны улсад), Марүзэн райбүрари, 1992, 153 дугаар тал 
арга барил зохих хэмжээгээр хуримтлагдаж ирсний ч тодорхой үр дүн мөн гэлтэй.

Хоёрт, хэдэн арван жилийн турш үзэл суртлын өөр системд хамааран, бие биеэс нь тусгаарлах хөшиг хаалт үйлчилсээр байсан ч нэгэн тивд оршдог, эдийн засгаа гайхалтай хурдацтай сэргээн босгож, дэлхийн өндөр хөгжилтэй орон болж чадсан бодит байдал нь Япон улстай харилцаа, хамтын ажиллагааг өргөтгөх явдлыг Монгол Улсын тухайд чухал шаардлага, зүй тогтол болгосон юм.

Эцэст нь, Зөвлөлтийн өөрчлөн байгуулалтын нөлөөгөөр манай улсад дэлхийн улс орнуудтай харилцан ашигтай хамтын ажиллагаа бэхжүүлэх үндсэн дээр улс орноо, эдийн засгаа үндэсний язгуур эрх ашигт тулгуурлан хөгжүүлэх чиг шугамыг чухалчлах болсон үйл явц нь Япон улстай харилцаа, хамтын ажиллагааг өргөтгөн хөгжүүлэх таатай боломжийг бий болгож, үүгээр хоёр орны харилцаанд цоо шинэ үе шат нээгдсэн юм”.

Энэ үе хүртэлх үйл явцыг ахмад дипломатч, Элчин сайд С.Дамбадаржаа гуай "Монгол Японы харилцааны дөлгөөн үе"7 гэх сайхан үгээр онож нэрлэсэн байдаг.

\section{Харилцааны идэвхжил, иж бүрэн түнилэлийн үе}

Харин Монгол Улс ардчилал, зах зээлийн нийгэмд хөл тавьсан 1990-ээд оноос Монгол, Японы харилцаа нийгэм, үзэл суртлын ялгаанаас ангижирч, цоо шинэ, үсрэнгүй хөгжлийн шатанд дэвших, өнөөгийн олон талын харилцаа, хамтын ажиллагааны үндэс суурь баттай тавигдах нөхцөл бүрэлдсэн юм. Монгол Улс шинэ Үндсэн хуулиа 1992 оны 1 дүгээр сард баталж, “ардчилал, хүний эрхийг дээдэлсэн хүмүүнлэг иргэний нийгэм байгуулах ${ }^{8}$-аa тунхаглан бүх улс оронд адил тэгшээр хандах гадаад бодлогын зарчмыг тодорхойлсон. Шинэ Үндсэн хуулийн үзэл санааны дагуу ардчилсан шинэчлэлийг гүнзгийрүүлэх, зах зээлийн харилцааг төлөвшүүлэх,

6 Б.Сэржав, Монгол Японы харилцаа ХХ зууны сүүлийн хагаст, Өргөө хэвлэл компани, Улаанбаатар., 2003, 66-67 дугаар тал.

7 С.Дамбадаржаа, “Өгөөжтэй хорин жил”, Дорно Өрнө сэтгүүл, 1(1992), 25-31 дүгээр тал.

8 Монгол Улсын Үндсэн хууль, Улаанбаатар, 1992. 
хүмүүнлэг ардчилсан иргэний нийгэм байгуулах гадаад таатай орчныг бүрдүүлэхэд чиглэсэн Монгол Улсын Гадаад бодлогын үзэл баримтлалыг 1994 онд батлав. Гадаад бодлогын үзэл баримтлалд Монгол Улсын гадаад бодлогын нэг гол чиглэлийг “АНУ, Япон... зэрэг өрнө дорнын өндөр хөгжилтэй гүрнүүдтэй найрсаг харилцаа хөгжүүлэх явдал" хэмээн заасан. Энэ үеэс дэлхийн бодлогод нөлөө бүхий, өндөр хөгжилтэй, ардчилсан улс орнуудыг цогц байдлаар “гуравдахь хөрш” хэмээн үзэх манай улсын олон тулгуурт, бие даасан гадаад бодлогод Япон улс чухал байр суурь эзэлж ирсэн юм.

Монгол Улс ардчиллын гараанд тулж ирсэн 1990 оны 2 дугаар сард БНМАУ-ын Сайд нарын Зөвлөлийн дарга Д.Содном Засгийн газрын тэргүүний хувиар өрнөдийн орнуудаас анх түрүүн Япон улсад албан ёсоор айлчилсан. Энэ айлчлалаар Сайд нарын Зөвлөлийн дарга Д.Содном, Япон улсын Засгийн газрын Ерөнхий сайд Т.Кайфутай хэлэлцээ хийж, хоёр улсын Засгийн газрын хооронд Худалдааны хэлэлцээр байгуулагдсан. Мөн 1991 оны 8 дугаар сард дэлхийн өндөр хөгжилтэй орнуудын Засгийн газрын тэргүүн нараас хамгийн түрүүнд Япон улсын Засгийн газрын Ерөнхий сайд Кайфу Тошики Монгол Улсад албан ёсны айлчлал хийсэн нь Монгол, Японы харилцааны түүхэнд эргэлт гаргах онцгой үйл явдал болж, хоёр орны харилцааг цоо шинэ түвшинд хөгжүүлэх үндсийг тавихад түүхэн Үүрэг гүйцэтгэсэн юм.

Тухайн үед Монгол Улс сонгон авсан ардчилсан хөгжлийн шинэ чиг шугамыг тууштай үргэлжлүүлэх, эдийн засгийн уналт, хямралыг даван туулж, ирээдүйн бие даасан хөгжлийн суурийг бий болгох, олон улсын тавцанд байр сууриа бататгах, бүс нутгийн интеграцид оролцох боломжийг бүрдүүлэх, цаашилбал Монгол Улсын аюулгүй байдал, бие даасан байдлыг бэхжүүлэх гэх зэрэг нэн эгзэгтэй асуудалтай тулгарч байв. Япон улсын хувьд манай улсын ардчилал, эдийн засгийн шинэ тогтолцоонд шилжих үйл явцыг анхнаас нь тууштай дэмжиж, эдийн засаг, нийгмийн амьдралд олон талт тусламж дэмжлэгийг үзүүлэн Монгол Улсыг дэмжих олон улсын механизмыг манлайлсан нь манай улсад шилжилтийн үеийн бэрхшээлийг даван туулах, улмаар орчин үеийн хөгжлийн суурийг бүрдүүлэхэд томоохон үүргийг гүйцэтгэсэн билээ. Тухайн

9 Монгол Улсын гадаад бодлогын үзэл баримтлал, Улаанбаатар, 1994. 
үеэс Япон улсын Засгийн газрын хөгжлийн албан ёсны тусламжийн хөтөлбөрүүд, Өвсний үндэс хөтөлбөрийн төслүүд эхэлж, төслийн тоо, цар хүрээ жилээс жилд нэмэгдэж, агуулга, ач холбогдлын хувьд гүнзгийрч ирсэн юм. Тухайлбал, IV цахилгаан станцын хэвийн ажиллагааг хангах, харилцаа холбооны Интелсат станц суурилуулах, Замын-Үүдийн ачаа шилжүүлэх байгууламжийг сайжруулах, эмнэлэг, сургуулиудыг өргөтгөн шинэчлэх, алслагдсан сумдад дизель станц суурилуулах, Улаанбаатар хотын авто зам, нийтийн тээвэр, төмөр замыг шинэчлэхээс эхэлсэн олон тооны төслийг Япон улсын дэмжлэг туслалцаатайгаар хэрэгжүүлж байлаа. Манай улсад авч ашигласан Япон улсын Засгийн газрын хөгжлийн албан ёсны тусламж 2016 оны байдлаар 115 тэрбум 158 сая иэний буцалтгүй тусламж, 125 тэрбум 944 сая иэний хөнгөлөлттэй зээл, 44 тэрбум 770 сая иэний техникийн хамтын ажиллагааны тусламж, нийт 286 тэрбум 282 сая иэн ${ }^{10}-$ д хүрчээ.

Энэ үеэс хоёр орны хооронд төр засгийн өндөр дээд хэмжээний айлчлал (Монгол Улсаас Ерөнхий сайд П.Жасрай 1993 онд, Ерөнхий сайд М.Энхсайхан 1997 онд, УИХ-ын дарга Н.Багабанди 1994 онд, УИХ-ын дарга Р.Гончигдорж 1999 онд, Ерөнхийлөгч Н.Багабанди 1998 онд, Гадаад харилцааны сайд нар 1992, 1995, 1997, 1998, 1999 онд Япон улсад, Япон улсын Парламентийн Зөвлөхүүдийн танхимын дарга Ю.Осада 1992 онд, Парламентийн Зөвлөхүүдийн танхимын дарга Ж.Сайто 1997 онд, Япон улсын Засгийн газрын Ерөнхий сайд Обүчи Кэйзо 1999 онд) тогтмол хэрэгжиж, харилцаа, хамтын ажиллагааны үндэс суурь, чиглэл зарчмыг тодорхойлсон Хамтарсан мэдэгдлүүд нийтлэгдэж, хоёр орны хамтын ажиллагааг харилцан ашигтай, нэг нь нөгөөгөө нөхөх түвшинд хүртэл хөгжүүлэх чиг бодлогыг тусгаж ирсэн. Монгол Улс, Япон улсын Засгийн газрын хооронд Худалдааны хэлэлцээр /1990/, Японы далайн чанад дахь залуучуудын сайн дурын байгууллагыг Монгол Улсад ажиллуулах хэлэлцээр /1991/, Агаарын хамтын ажиллагааны хэлэлцээр /1993/-үүд байгуулагдан хамтын ажиллагааны эрх зүйн үндэс улам өргөжиж, хоёр орны харилцаа урьдын тогтуун байдал, хязгаарлагдмал хүрээнээс халин гарч, улс төр, худалдаа, эдийн засаг, соёл, боловсрол, хүмүүнлэгийн зэрэг өргөн чиглэлээр эрс идэвхжиж эхэлсэн юм.

10 www.mn.emb-japan.go.jp/mn/bi_relation/econ_coop/econcoop-list.html 
Монгол Японы харилцаа ийнхүҮ маш богино хугацаанд олон салбарыг хамран эрчимжиж, цар хүрээ нь өргөжин, 1990-ээд оны сүүлийн хагасаас чанарын шинэ шатанд шилжиж, Иж бүрэн түншлэлийн харилцаа хөгжих үйл явц эхэлсэн юм. Анх Япон улсын Гадаад хэргийн яамны Азийн газрын дарга Р.Като манай улсад 1996 оны 8 дугаар сард айлчилж, хоёр орны харилцааг урт хугацаанд тогтвортой хөгжүүлэхийн төлөө "Иж бүрэн түншлэлийн харилцаа" болгон хөгжүүлэх зарчмыг санал болгож байжээ. Ерөнхий сайд М.Энхсайханы 1997 оны 2 дугаар сард Япон улсад хийсэн албан ёсны айлчлалын үед хоёр тал харилцааг XXI зуунд чиглүүлж, Иж бүрэн түншлэлийн харилцаа болгон хөгжүүлэх зорилтыг дэвшүүлсэн Хамтарсан Мэдэгдэл нийтэлсэн. Хоёр орны Иж бүрэн түншлэлийн харилцааны зарчмыг “нэгдүгээрт, харилцан ойлголцсон, бие биеэ хүндэтгэсэн, улс төрийн урт хугацааны харилцаа, хоёрдугаарт, олон улсын харилцааны хэм хэмжээнд нийцсэн худалдаа, эдийн засгийн харилцан ашигтай түншлэл, гуравдугаарт, соёл, боловсрол, шинжлэх ухаан-технологи, хүмүүнлэгийн салбарыг хамарсан харилцаа, дөрөвдүгээрт, дэлхий дахины глобал бүс нутгийн харилцааны асуудлыг шийдвэрлэхэд хамтран ажиллах явдал"11 байхаар хоёр тал харилцан тохиролцож, 1998 оны 5 дугаар сард Ерөнхийлөгч Н.Багабандийн Япон улсад хийсэн айлчлалын үеэр “Иж бүрэн түншлэлийн харилцаа"-г бэхжүүлэн хөгжүүлэх зорилтоо хоёр тал дахин нотолсон юм.

Иж бүрэн түншлэлийн шатанд хоёр орны харилцаа, хамтын ажиллагааг гүнзгийрүүлж хөгжүүлэх зорилтыг тусгасан хөтөлбөрийн чанартай баримт бичгүүд удаа дараа батлагдан хэрэгжсэн. “Япон улсаас Монгол Улсад үзүүлэх 5 жилийн тусламжийн хөтөлбөр” /2004.11/ -ийн дагуу манай улсын эдийн засгийн тогтвортой өсөлтийг дэмжих зорилгоор зах зээлийн тогтолцоог дэмжих боловсон хүчин бэлтгэх, хөдөө аж ахуйг хөгжүүлэх, байгаль орчныг хамгаaлах, эдийн засгийг хөгжүүлэхэд чиглэсэн дэд бүтцийг бий болгох ${ }^{12}-$-д тусламжийг чиглүүлэн, олон томоохон төсөл хэрэгжиж иржээ.

2007 оны 2 дугаар сард “Монгол, Японы хамтын ажиллагааны цаашдын 10 жилийн үндсэн хөтөлбөр”-ийг байгуулсан. Энэ

11 Монгол Улсын Гадаад харилцааны яамны архив. Ф-59, хн-58/173

12 http://www.mofa.go.jp/mofaj/gaiko/report.html 
хөтөлбөрийн хэрэгжилтийн хүрээнд хоёр орны улс төрийн яриа хэлэлцээ, бодлогын зөвлөлдөх уулзалтууд тогтмолжиж, худалдаа, хөрөнгө оруулалтыг өргөжүүлэх, технологи шилжүүлэх, байгаль орчныг хамгаaлах, соёл, боловсрол, хүмүүнлэгийн хамтын ажиллагааг хөгжүүлэх чиглэлээр тодорхой алхмууд хийгдсэн. Хоёр талын худалдааг өргөтгөх, ялангуяа Японы хувийн хэвшлийнхний Монгол дахь хамтын ажиллагааны сонирхлыг дээшлүүлэх, хөрөнгө оруулалтыг нэмэгдүүлэхэд чиглэсэн Монгол, Японы Засгийн газар болон хувийн хэвшлийн хамтарсан худалдаа, хөрөнгө оруулалтын зөвлөлдөх уулзалтыг удаа дараа зохион байгуулах зэргээр хоёр орны хамтын ажиллагааны механизмыг олон салбарт бүрдүүлсэн нь бодит үр дүнгээ өгсөн юм.

Хөгжлийн тусламжийг үр ашигтай зарцуулах, эдийн засгийн тогтвортой өсөлтийг хангах замаар ядуурлыг бууруулахад чиглэсэн Монгол Улсын үйл ажиллагааг дэмжих зорилго бүхий тусламжийн шинэ хөтөлбөрийг Япон улсын Засгийн газар 2012 оны 4 дүгээр сард баталсан. Энэ хөтөлбөрт Уул уурхайн салбарын тогтвортой хөгжил, Баялагаас олох орлогын зохистой удирдлага, засаглалыг бэхжүүлэх; Бүх хүнд өгөөжтэй өсөлтийг хангахад чиглэсэн дэмжлэг, үүнд жижиг дунд үйлдвэрийн хөгжлөөр дамжуулан аж үйлдвэрийн салбарыг төрөлжүүлж, ажлын байр нэмэгдүүлэх, нийгмийн суурь үйлчилгээг сайжруулах, Улаанбаатар хотын чадавхийг бэхжүүлэх, дэд бүтцийг сайжруулах, хот төлөвлөлт, удирдлагын чадавхийг бэхжүүлэхэд үзүүлэх дэмжлэг ${ }^{13}$-ийг тэргүүлэх чиглэл байхаар заажээ. "Улаанбаатар хотын зам тээврийн нөхцлийн сайжруулах, гүүрэн гарц барих”, “Бага, дунд боловсролын сургуулийн барилга барих”, “Улаанбаатар хотын усан хангамжийг сайжруулах", “Цэнгэг усны нөөц ба байгаль хамгаалах", “Хүний нөөцийн тэтгэлэг”-ийн тусламжийн хөтөлбөрүүд, "IY цахилгаан станцийн хүчин чадлыг сайжруулах”, “Жижиг, дунд үйлдвэрийг хөгжүүлэх, байгаль орчныг хамгаалах 2 үе шаттай зээл”, “Улаанбаатар хотын шинэ нисэх онгоцны буудал барих” зэрэг иэний хөнгөлөлттэй зээлийн төслүүд хэрэгжиж ирсэн юм.

1990 оноос хойш богино хугацаанд хоёр орны харилцаа эрчимтэй хөгжиж “Иж бүрэн түншлэл”-ийн түвшинд хүрсэн хүчин зүйлийг

13 http://www.mn.emb-japan.go.jp/ 
доктор Ц.Батбаяр “нэгд, Монгол Улсын Засгийн газар, ард түмэн 1990 оноос хойш ардчилал, зах зээлийн эдийн засгийг эргэлт буцалтгүй сонгон авч тэр замаар тууштай замнахаар шийдсэн явдал 1972 оноос хойш хоёр орны харилцаанд байгаагүй цоо шинэ нөхцөл байдлыг бий болгож, ардчиллын нийтлэг үнэт зүйлсийн үндсэн дээр хоёр орны харилцааг “Иж бүрэн түншлэл”-ийн түвшинд хөгжүүлэх бололцоог нээж өгөв. Японы хувьд Монголын энэхүҮ ардчилсан өөрчлөлт нь түүний хоёр хөрш төдийгүй, Азийн авторитар дэглэмтэй бусад орнуудын хувьд үлгэр жишээ болж өгч байгаа бөгөөд Монголын туршлага, Монголын загварыг амжилтад хүргэх гэсэн тууштай сонирхол байгаа нь харагдаж байна.

Хоёрт, Монголын удирдагчдын ХX зууны эхнээс эхэлсэн “Гуравдахь хөрш"-ийн бодлого 1990 оноос эрчимжиж, хоёр хөршөөс гадна манай гурав дахь бат бэх гадаад тулгуур болох Япон орныг АНУ, Европын холбоо бусад субьектүүдтэй эн зэрэгцүүлэн тавих болсон.

Гуравт, бас сэтгэл зүйн хүчин зүйлийг хайхрахгүй байж болохгүй. Зүүн өмнөд Азийн зарим орнуудтай адилгүй Монголын хувьд Япон орон, япончууд нь дэлхийн II дайны үед Монгол орныг эзлэн түрэмгийлж, элдэв харгислал үйлдэж байгаагүй, “түүхийн ял зэм“" acyух зүйл үгүй гэж хэлж болно. Нөгөө талаас япончуудын хувьд Монгол орон, монголчууд нь Төв Азийн зүрхэнд орших “морьтон үндэстэн” хэмээн сэтгэл зүрхний угаас дотно ханддаг бөгөөд дэлхийн II дайны дараа өөрсдийн амсаж байсан зовлон зүдгүүрийг 1990 оны дараах Монголын эдийн засаг унасан, дэлгүүр лангуу нь хоосорсон, “гудамжны хүүхэд” олширсон зэрэг сэтгэгдлээр хүлээн авч тусламжийн халуун гараа сунгахаар шийдэх болсон нь маргаангүй юм" ${ }^{\prime 14}$ хэмээн дүгнэсэн байна.

\section{Стратегийн түнилэлийн харилцааны өрнөл}

Монгол, Японы хооронд Иж бүрэн түншлэлийн зарчимд тулгуурлан хөгжүүлж ирсэн харилцааг шинэ түвшинд дэвшүүлэн Стратегийн түншлэл байгуулах хамтын шийдвэрт 2010 оны 11 дүгээр

14 Ц.Батбаяр, Монгол ба Япон $X X$ зуунд, Бэмби сан хэвлэлийн газар, Улаанбаатар, 2012, 198 дугаар тал. 
сард Ерөнхийлөгч Ц.Элбэгдоржийн Япон улсад хийсэн айлчлалын үеэр талууд санал нэгдсэн юм. Энэ айлчлалын үеэр Монгол Улсын Ерөнхийлөгч Ц.Элбэгдорж Япон улсын Ерөнхий сайд Н.Кан нарын хооронд хэлэлцээ явагдаж, “2007 онд байгуулагдсан Монгол, Японы хамтын ажиллагааны 10 жилийн үндсэн хөтөлбөрийн дагуу Иж бүрэн түншлэлийн харилцааг хөгжүүлж ирсэн хамтын хүчин чармайлт тодорхой үр дүнд хүрч, улмаар хоёр орны харилцааг дараагийн дээд шатанд дэвшүүлэн, харилцан ашигтай, бие биеэ нөхсөн харилцааг өргөн хүрээнд батжуулан хөгжүүлэх нөхцлийг бүрдүүлж өгсөн"15-ийг тэмдэглэсэн. Хоёр тал Иж бүрэн түншлэлийн харилцааг стратегийн түншлэлийн шатанд хөгжүүлэх зорилт дэвшүүлсэн "Стратегийн түншлэлийн харилцаа байгуулахад чиглэсэн Монгол Улс Япон улсын хамтарсан Мэдэгдэл”-ийг /2010.11.19/ нийтэлж, хөгжлийн шинэ шатанд хоёр улс

1. Өндөр дээд хэмжээний яриа хэлэлцээг идэвхжүүлэх

2. Эдийн засгийн харилцааг идэвхжүүлэх, харилцан ашигтай хамтын ажиллагааг хөгжүүлэх

3. Хүн солилцоо, соёлын харилцааг идэвхжүүлэх

4. Бүс нутаг, глобал асуудлаарх хамтын ажиллагааг бэхжүүлэх зэрэг салбарт харилцаа, хамтын ажиллагааг гүнзгийрүүлэн хөгжүүлэх зорилт дэвшүүлсэн.

Монгол Улсын Ерөнхий сайд Сү. Батболд /2012.05/, Ерөнхий сайд Н.Алтанхуяг /2012.10/ нар 2012 онд Япон улсад албан ёсны айлчлал хийсэн. 2013 онд Япон улсын Ерөнхий сайд Абэ Шинзо /2013.03/ Монгол Улсад, Монгол Улсын Ерөнхий сайд Н.Алтанхуяг /2013.09/ Япон улсад харилцан айлчилсан нь хоёр улсын харилцааг эрчимжүүлэх, эдийн засгийн хамтын ажиллагааг шинэ шатанд гаргах, хамтын ажиллагааны бодлого чиглэлийг тодорхойлоход шинэ түлхэц өгсөн юм. Японы Ерөнхий сайд Абэ Шинзогийн айлчлалын үеэр талууд хоёр улсын улс төрийн харилцаа, эдийн засгийн хамтын ажиллагаа, иргэдийн солилцоо, соёл боловсролын салбар, олон улс, бүс нутгийн хэмжээний өргөн хамтын ажиллагааны талаар харилцан санал солилцож, Монгол Улсын Засгийн газрын Ерөнхий

15 “Стратегийн түншлэлийн харилцаа байгуулахад чиглэсэн Монгол Улс, Япон улсын Хамтарсан мэдэгдэл” 2010.11.19. 
сайд Н.Алтанхуяг “Япон улстай Стратегийн түншлэлийн харилцаа, хамтын ажиллагаа хөгжүүлэх нь Монгол Улсын гадаад бодлогын тэргүүлэх чиглэлийн нэг юм. Иймд Монгол Японы стратегийн түншлэлийг нийгмийн бүх салбарт эрчимжүүлэн хөгжүүлэх, түүний дотор эдийн засгийн хамтын ажиллагааг шинэ шатанд гаргахад яриа хэлэлцээ чиглэгдлээ” хэмээн онцлон тэмдэглэсэн. Мөн “Монгол Улсад ардчиллыг бэхжүүлэх, зах зээлийн эдийн засгийн тогтолцоог бүрдүүлэх, орчин үеийн хөгжлийн суурийг тавихад анхнаас нь нэн чухал дэмжлэг үзүүлсэн, манай гол түнш орон, гуравдахь хөрш Япон улстай цаашид харилцаа хамтын ажиллагаагаа улам зузаатгаж хамтран ажиллах байр суурьтай байгаa""16-г мэдэгджээ.

Япон улсын Засгийн газрын Ерөнхий сайд Ш.Абэ Японы гадаад бодлого дахь Монгол Улсын ач холбогдол өсч байгааг тэмдэглэсэн. Японы Ерөнхий сайд хоёр орны Стратегийн түншлэлийн харилцааг эрх чөлөө, ардчилал, энх тайван, бие биедээ харилцан туслах үзэл санааны дагуу бэхжүүлэн хөгжүүлэх санал гаргаж, улмаар Монгол Улсын эдийн засгийн тогтвортой хөгжлийг дэмжихэд чиглэсэн хоёр талын худалдаa, хөрөнгө оруулалтыг нэмэгдүүлэх, эдийн засгийн хамтын ажиллагааг эрчимжүүлэх зорилготой “Эрч” санаачилга дэвшүүлсэн. “Эрч” санаачилгад:

1. Хөрөнгө оруулалт, бизнесийн орчныг сайжруулах

2. Манай улсын эдийн засгийн дунд болон урт хугацааны тогтвортой хөгжлийг дэмжихэд чиглэсэн хамтын ажиллагааны талаар тусгаж, сургалтын зориулалтын шинэ эмнэлэг барих, Олон улсын шинэ нисэх онгоцны буудал, Дарханы нефть боловсруулах үйлдвэр байгуулах, Таван толгойн нүүрсний ордын ашиглалтын төсөлд хамтран ажиллах зэрэг саналыг дэвшүүлжээ.

Монгол Улсын Ерөнхий сайд Н.Алтанхуягийн Япон улсад хийсэн айлчлалын үед хоёр орны харилцаа, хамтын ажиллагааны ойрын жилүүдийн чиглэл хандлага, агуулгыг тодорхойлсон “Монгол Японы стратегийн түншлэлийн дунд хугацааны хөтөлбөр (2013-2017)",17 байгуулж, хоёр орны стратегийн түншлэлийн тулгуур болох

1. Улс төр, аюулгүй байдлын салбар

2. Эдийн засгийн хамтын ажиллагааны салбар

16 www.mfa.gov.mn

17 www.mn.emb-japan.go.jp 
3. Соёл, иргэд хоорондын солилцооны салбарт өргөн хүрээтэй олон чиглэлийн хамтын ажиллагааг өрнүүлэхээр заасан.

Энэ хөтөлбөрийн дагуу байгаль орчны тогтвортой хөгжлийг дэмжих, боловсон хүчин бэлтгэх, суурь дэд бүтцийн хөгжил, бүтээн байгуулалтын чиглэл зэрэг өргөн чиглэлээр олон төсөл хөтөлбөр хэрэгжсэний дотор “Жижиг дунд үйлдвэрийг дэмжих, байгаль орчныг хамгаалах 2 үе шаттай зээлийн төсөл”, “Инженер техникийн дээд боловсрол" төсөл, “Улаанбаатар хотын олон улсын нисэх онгоцны шинэ буудал барих төсөл”, “Дулааны IY цахилгаан станцийн үр ашгийг дээшлүүлэх төсөл”-үүд хэрэгжиж, үр дүнгээ өгч эхлэв.

“Монгол, Японы төр, хувийн хэвшлийн зөвлөлдөх уулзалт" 7 удаа зохион байгуулагдаж, хоёр улсын эдийн засгийн харилцааны өргөн цар хүрээтэй асуудлыг хэлэлцэж ирсэн нь хоёр орны хувийн салбарын хамтын ажиллагааг урагшлуулахад үр дүнтэй болсон. 2016 оныг хүртэл Япон улсаас манай улсад нийт 262 сая долларын хөрөнгө оруулалт хийгдэж, түүний ихэнх боловсрол, нийгмийн салбарт ногджээ. 2015 оны байдлаар Японы 551 компани Монгол Улсад бүртгэгдэн үйл ажиллагаа явуулж байжээ ${ }^{18} .2013$ онд Японы хөрөнгийн зах зээл дээр Монгол Улсын Хөгжлийн банк 30 тэрбум иэний Самурай бонд босгоход Япон улсын хамтын ажиллагааны банк баталгаа гаргав. Ингэснээр Монгол Улсын Засгийн газар болон Хөгжлийн банкны санхүүжилтийн эх үүсвэр нэмэгдэж, Японы хувийн хэвшлийнхэнд хөрөнгө оруулалтын шинэ боломж нээгдэв ${ }^{19}$.

Засгийн газар, хувийн хэвшлийн Зөвлөлдөх уулзалтаас гадна манай хоёр улсын салбар яамдын хоорондын хамтын ажиллагаа, тухайлбал, байгаль орчин, уул уурхай, зам тээвэр, барилга хот байгуулалт, хөдөө аж ахуйн асуудал хариуцсан яамдын хооронд шууд хамтын ажиллагаа төлөвшиж, салбарын зөвлөлдөх уулзалт тогтмолжиж ирлээ. Түүнчлэн хоёр орны харилцаа улс төр, аюулгүй байдал, батлан хамгаалах, бүс нутаг олон улсын тавцан хийгээд худалдаа, эдийн засаг, соёл иргэд хоорондын харилцаа өргөжин тэлж, харилцан ойлголцол гүнзгийрч ирсэн үйл явц, түүний үр дүнг

18 http://eagle.mn/r/18538 Ерөнхий сайд Ж.Эрдэнэбатын Япон улсад хийсэн айлчлал

19 Монгол Японы стратегийн түншлэлийн дунд хугацааны хөтөлбөр (2017-2021) 
“Монгол Японы стратегийн түншлэлийн дунд хугацааны хөтөлбөр (2017-2021)"-т тусгагдсан үнэлэлт дүгнэлтээс харж болохоор байна.

\section{Монгол Японы эдийн засгийн түншлэлийн эхлэл}

Япон улстай тогтоон хөгжүүлж буй худалдаа, хөрөнгө оруулалтыг урагшлуулах, эдийн засгийн хамтын ажиллагааг гүнзгийрүүлэх, Стратегийн түншлэлийн харилцааг бэхжүүлэхэд нэн чухал ач холбогдолтой “Монгол Японы Эдийн засгийн түншлэлийн хэлэлцээр” 2016 оны 6 дугаар сараас хүчин төгөлдөр болж хэрэгжиж эхлээд байна.

“Эдийн засгийн түншлэлийн тухай Монгол Улс, Япон улс хоорондын хэлэлцээрт гарын үсэг зурсантай холбогдуулан гаргасан Хамтарсан Мэдэгдэл”-д тэмдэглэсэнчлэн “Энэхүу хэлэлцээр нь хоёр орны хөрөнгө оруулалт, үйлчилгээ, бараа бүтээгдэхүүний урсгал, цаашлаад иргэд хоорондын харилцан солилцоог нэмэгдүүлж, хувийн хэвшлийнхэнд бизнесээ тэлэх, хөрөнгө оруулалт хийх шинэ боломжийг бүрдүүлж, улмаар бие биенээ харилцан нөхсөн хоёр орны эдийн засгийн харилцааг шинэ шатанд гаргана" ${ }^{20}$. УГ хэлэлцээрээр олон улсын жишгийн дагуу тухайн оны худалдааны дүнгийн 90 гаруй хувийг импортын гаалийн тарифаас шууд болон 10 жилийн хугацаанд үе шаттайгаар чөлөөлөхөөр харилцан тохиролцсон. Монголын тал 97 бүлгийн 5700 орчим төрлийн бараа, Японы тал 97 бүлгийн 9300 орчим төрлийн барааны импортын гаалийн тарифийг бууруулахаар болсон юм ${ }^{21}$.

Мөн Япон болон бусад улсад экспортлох Монгол Улсад үйлдвэрлэсэн бараа бүтээгдэхүүний чанарыг дээшлүүлэх, тоо хэмжээг нэмэгдүүлэхэд дэмжлэг үзүүлэх зорилгоор “Монголын экспортыг нэмэгдүүлэх, аж үйлдвэрийг төрөлжүүлэх зорилго бүхий “Эрч+ санаачилга" хэрэгжүүлэх саналыг Япон улсын Ерөнхий сайд Ш.Абэ 2014 оны 7 дугаар сард дэвшүүлсэн ${ }^{22}$. Ийнхүү хоёр

20 Эдийн засгийн түншлэлийн тухай Монгол Улс, Япон улс хоорондын хэлэлцээрт гарын үсэг зурсантай холбогдуулан гаргасан Хамтарсан Мэдэгдэл, Токио хот, 2015 оны 2 дугаар сарын 10-ны өдөр

21 Засгийн газрын мэдээ, Улаанбаатар, 2015.03.25, № 053(077)

22 Мөн тэнд 
орны худалдааг эрчимтэй өсгөх, Японы шууд хөрөнгө оруулалтыг нэмэгдүүлэх, манай улсын аж үйлдвэрийн төрөлжилтийг урагш ахиулах, эдийн засгийн бие биеэ нөхсөн хамтын ажиллагааг бодит амьдрал дээр хэрэгжүүлэхэд чухал ач холбогдол бүхий хэлэлцээр байгуулагдан, хэрэгжиж эхэллээ. Дэлхийн Худалдааны Байгууллагын гишүүнээр элссэнээс хойш Монгол Улсын өмнө тавигдаж ирсэн түнш оронтой Чөлөөт худалдааны хэлэлцээр байгуулж хэрэгжүүлэх зорилт ийнхүҮ Япон улстай байгуулсан Эдийн засгийн түншлэлийн хэлэлцээрээр биеллээ оллоо.

Эдийн засгийн түншлэл нь манай улсын хувьд Японы байгальд ээлтэй дэвшилтэт технологи, ноу хау-г нэвтрүүлэх, ажлын байр нэмэгдэх, ядуурал буурах, үндэсний үйлдвэрлэл хөгжиж, гадаад зах зээл дээр өрсөлдөх чадвараа дээшлүүлэх, экспортын барааны нэр төрлийг олшруулах, улмаар манай улсын бараа бүтээгдэхүүн Японы зах зээл төдийгүй бүс нутгийн орнуудын зах зээлд нэвтрэхэд таатай боломжийг нээнэ. Харин Японы хувьд коксжих нүүрс төдийгүй бусад эрдэс баялгийн нийлүүлэлтийн баталгаатай байдлаа хангах гэсэн харилцан бие биеийг нөхөх давуу талтай байх болно. Мөн Японы өндөр технологийг нэвтрүүлж, байгаль орчны хамгааллаа сайжруулж чадвал хөрш орнуудын болон бүс нутгийн хувьд энэ эдийн засгийн түншлэлийн үр дүн харагдах болно. Цаашилбал,энэ хэлэлцээр манай улсаас хоёр хөрш хийгээд бусад улстай Чөлөөт худалдааны хэлэлцээр байгуулж хамтран ажиллахад чухал туршлага болох, урт хугацаанд дотоод гадаад дахь эдийн засгийн хамтын ажиллагаа эрчимжиж, эдийн засгийн цар хэмжээ өсөн тэлэхэд ч томоохон түлхэц болох биз ээ.

Харин Япон улсын Монголтой Эдийн засгийн түншлэлийн хэлэлцээрээр хамтран ажиллахын гол зорилго, эрх ашгийн тухайд Японы хэвлэлүүд “Японы хувьд БНАСАУ-тай дипломат харилцаа бүхий Монгол Улстай хамтын ажиллагаагаа гүнзгийрүүлэх, хулгайлагдсан япон иргэдийн асуудлыг шийдвэрлэхэд Монголын талаас дэмжлэг авах зорилт тавьж байгаa"23, “Япон улсын эрдэс баялгийн тогтвортой нийлүүлэлтийг хангах, түүний тулд Японы үйлдвэр, компаниудад Монголд хөрөнгө оруулалт хийхэд нь дөхөмтэй нөхцлийг бий болгох зорилт тавьж байгаа”24, “...Монгол

23 朝日新聞、2014.07.21.

24 毎日新聞、2014.07.22. 
Улс алсдаа Азид хөгжлийн ирээдүйтэй улс тул Японы үйлдвэрүүд тэнд зах зээлээ тэлэх найдвар бий”25, “Японы тал Монголтой хамтын ажиллагаа бэхжүүлэхийн цаад талд Монголтой хил залгадаг Хятад улсыг хязгаарлах зорилго бас бий, харин Монголын хувьд хөрш Хятад Улс, ОХУ-аас хамааралтай эдийн засгийн бүтцээсээ ангижрах гэсэн зорилго энэ хэлэлцээрийн ард бий" ${ }^{26}$ гэхчлэн дүгнэсэн.

УИХ-ын дарга М.Энхболдын энэ 2017 оны 3 дугаар сард Япон улсад хийсэн албан ёсны айлчлалын үеэр хоёр улсын гадаад хэргийн сайд нар "Монгол Японы стратегийн түншлэлийн дунд хугацааны хөтөлбөр (2017-2021)"'-т гарын үсэг зурж баталсан юм. Энэ хөтөлбөр 2014-2017 онд хэрэгжсэн хоёр орны Стратегийн түншлэлийн анхны дунд хугацааны хөтөлбөрийн хэрэгжилтийн үр дүнд олсон амжилтыг дүгнэж, 2021 он хүртэлх зорилтыг тодорхойлсон бодлогын чухал баримт бичиг болсон. 2017-2021 онд хэрэгжүүлэх дунд хугацааны хөтөлбөрт

I. Улс төр, аюулгүй байдлын салбарын хамтын ажиллагааны хүрээнд Монгол Японы харилцааг цаашид улам гүнзгийрүүлэн хөгжүүлж, бүс нутгийн тогтвортой байдал, хөгжил цэцэглэлтийн төлөөх түншлэлийг бэхжүүлэх

II. Эдийн засгийн харилцааны хүрээнд Монгол Улсын эдийн засгийг сэргээн хөгжүүлж, хоёр улсын худалдаа, эдийн засгийн харилцаа, хамтын ажиллагааг эрчимжүүлэх

III. Соёл, иргэд хоорондын харилцаа, хүний нөөцийг бэхжүүлэх хүрээнд харилцан ойлголцол, найрамдал нөхөрлөлийг бататган хөгжүүлэхийн тулд бүх түвшний хамтын ажиллагааг өргөжүүлэхэд чиглэсэн зорилтуудыг нарийвчлан тусгажээ.

\section{Дугнэлт}

Монгол Улс Япон улстай дипломат харилцаа тогтоосноос хойш 45 жилийн хугацаа улиран одлоо. Энэ харилцаа эхний үед дэлхий хоёр туйлд хуваагдан бие биеийн эсрэг сөрөн зогсч байсан Хүйтэн дайны үе болон социалист системийн уналтаар Монгол Улс ардчилал, зах

\footnotetext{
SankeiBiz, 2014.07.23.

26 JIJI PRESS, 2014.07.22.
} 
зээлийн тогтолцоонд шилжин цоо шинээр хөгжлийн гарааг эхэлсэн огцом хувьсал бүхий өвөрмөц түүхэн цаг хугацааны сорилтыг туулж, хамтын ажиллагааны шинэ шинэ хэлбэрийг нээн олж, өргөжин тэлсээр эдүгээ Стратегийн түншлэл, Эдийн засгийн түншлэлийн түвшинд хүрч гүнзгийрэн хөгжиж байна. Манай улсад ардчилсан шинэчлэлийг гүнзгийрүүлэх, зах зээлийн харилцааг төлөвшүүлэх, хөгжил дэвшлийн суурийг бэхжүүлж, ард түмний аж амьдралыг дээшлүүлэхэд Япон улстай тогтоон хөгжүүлж ирсэн тал бүрийн харилцаа, хамтын ажиллагаа ач холбогдлоо өгсөөр ирсэн.

Эдийн засгийн түншлэлийн хамтын ажиллагаа, стратегийн түншлэлийн дунд хугацааны шинэ хөтөлбөрийн хэрэгжилт нь хоёр орны хамтын ажиллагааны өнөөгийн өргөн боломжийг бүтээлчээр ашиглаж Япон улсын дэлхийд хүлээн зөвшөөрөгдсөн тэргүүний технологи, ноу хау, шилдэг туршлага, менежментийг өөрийн онцлогт тохируулан нэвтрүүлэх, түүний үндсэн дээр үндэсний үйлдвэрлэлийг хөгжүүлж өрсөлдөх чадвараа дээшлүүлэх, эдийн засгийн бие даасан байдлыг бататгах, улс орныг авч явах үндэсний боловсон хүчнээ бэлтгэх зэрэг өргөн хүрээтэй бололцоог олгож байна. Ийм хамтын ажиллагааны эхлэлийг уул уурхайн салбарт сайн чанарын нүүрсийг Японы зах зээлд худалдан борлуулах гэрээг Энержи ресурс компани Сүмитомо компанитай хийсэн, хөдөө аж ахуйн салбарт япон технологийг нэвтрүүлж, монгол малын сүүгээр хуурай сүү үйлдвэрлэх хамтарсан үйлдвэрийг хэдэн аймагт байгуулахаар Дрима милк компани Японы Присай компанитай санамж бичиг байгуулсан, мөн Японы хөрөнгө оруулалттай хамтарсан үйлдвэр байгуулж бүх төрлийн батерейг дотооддоо үйлдвэрлэн экологийн аюултай хог хаягдлын импортыг бууруулахаар тохиролцоод байгаа зэргээс харж болохоор байна. Товчоор хэлэхэд Монгол Улс Тогтвортой хөгжлийн үзэл баримтлал-2030 /2016/, Ногоон хөгжлийн бодлого /2014/, Үндэсний аюулгүй байдлын үзэл баримтлал /2010/ зэрэгт тусгагдсан тогтвортой хөгжлийн стратеги зорилтоо амжилттай хэрэгжүүлэхэд манай улсын анхны эдийн засгийн түншлэлт орон Япон улстай тогтоон хөгжүүлж буй харилцааны хүчин зүйл чухал нөлөөтэй байх нь маргаангүй. 


\section{Ном зүй}

1. Монгол Улсын Үндсэн хууль, УБ., 1992 он

2. Монгол Улсын гадаад бодлогын үзэл баримтлал, УБ., 1994

3. Монгол Улсын Гадаад харилцааны Яамны архив, Ф-59

4. “Стратегийн түншлэлийн харилцаа байгуулахад чиглэсэн Монгол Улс Япон улсын Хамтарсан Мэдэгдэл” 2010.11.19

5. Эдийн засгийн түншлэлийн тухай Монгол Улс, Япон улс хоорондын хэлэлцээрт гарын үсэг зурсантай холбогдуулан гаргасан Хамтарсан Мэдэгдэл, Токио хот, 2015 оны хоёрдугаар сарын 10-ны өдөр

6. Монгол Японы стратегийн түншлэлийн дунд хугацааны хөтөлбөр (2014-2017)

7. Монгол Японы стратегийн түншлэлийн дунд хугацааны хөтөлбөр (2017-2021)

8. Ц Ц.Батбаяр “Монгол ба Япон ХХ зуунд” Бэмби сан хэвлэлийн газар, УБ., 2012

9. С.Дамбадаржаа Өгөөжтэй хорин жил “Дорно Өрнө” сэтгүүл, 1992, №1, 25-31-р тал

10. Б.Сэржав. Монгол Японы харилцаа XX зууны сүүлийн хагаст, “Өргөө” хэвлэлийн компани, УБ., 2003

11. Засгийн газрын мэдээ сонин

12. Асахи сонин

13. Майничи сонин

14. Санкэй сонин

15. http://www.mn.emb-japan.go.jp/

16. http://www.mofa.go.jp/policy/global_and_oda.html

17. http://www.mofa.go.jp/mofaj/gaiko/report.html

18. www.mfa.gov.mn

19. www.mn.emb-japan.go.jp/mn/bi_relation/econ_coop/econcooplist.html 


\section{DIPLOMATIC RELATIONS BETWEEN MONGOLIA AND JAPAN: INTENSE AND TRENDS}

B.Serjav

45 years have passed since Mongolia established the diplomatic relation with Japan. This relationship sparked a unique evolution of the period of cold war and the collapse of the socialist system, with the evolution of Mongolia's transition to democracy and the market system. At present, the bilateral relation has been deepening and developing both Strategic Partnership and Economic Partnership. The implementation of both Economic Partnership Agreement and the new middle plan of Strategic Partnership Agreement between Mongolia and Japanis giving the wide-ranged possibility making use of joint enterprisesof both countries effectively and the Japanese worldwide advanced technology, know-how, deep experience, and management according to the characteristic of its own country. Mongolia makes domestic industries develop onto the basics, improves competitiveness, strengthens economical independence and brings up state human resources, and so on.

Keywords: Diplomatic relations between Mongolia and Japan, Mongolia's democracy, market system, Strategic Partnership between Mongolia and Japan, Economic Partnership between Mongolia and Japan 